\title{
Developing and analysing different definitions of operational excellence
}

\author{
Kai Mueller ${ }^{1} \cdot$ Eckehard Mueller $^{2} \mathbb{D}$
}

Received: 25 September 2020 / Accepted: 12 December 2020 / Published online: 4 January 2021

(c) The Author(s) 2021

\begin{abstract}
Operational Excellence is an expression, which is used in many ways in the context of transforming a company to play a relevant roll on the market in the future. A basic question is if these words are only a hype or does a scientific background exist? How is operational excellence is defined? An investigation is made to answer these questions and try to define operational excellence in the background of the actual developments.
\end{abstract}

Keywords Operational excellence $\cdot$ Definition $\cdot$ Tools

\section{Introduction}

A great discussion for several years has been that processes in companies need to be optimized to be competitive for the future. On one hand, the focus is on the internet of things and cyber physical systems or in German called "Industry 4.0" (Kagermann et al. 2013). On the other hand, tools like Kaizen or Six Sigma have always been implemented in companies to strengthen their operational excellence (OPEX). OPEX is mostly used as a term, but different stakeholders understand OPEX in different ways. Sometimes OPEX is used inflationary.

\section{Basic idea}

The first investigation should be an analysis, if OPEX has been established in the scientific literature and how dominant the phrase is. If this fact can be proved it should be investigated in which context OPEX is used and if there is a

Eckehard Mueller

eckehard.mueller@hs-bochum.de

Kai Mueller

kai.sebastian.mueller@gmx.de

1 Steinbeis-Transfercenter for Spring Technology, Component Behavior and Process, Langerfeldstraße 53 c, 58638 Iserlohn, Germany

2 Bochum University of Applied Sciences, Lennershofstr. 140, 44801 Bochum, Germany scientific definition of OPEX. In this area, a mostly different definition will exist concerning the different points of view. E. g. from the view of the production another definition will be created from the economic position. The industrial world is always in a dynamic change. Questions that need to be answered are:

- Do the found definitions reflect the actual development?

- Is it possible to find a common description or definition of OPEX?

\section{Establishing the word OPEX in the scientific literature}

Every theme in the scientific community has a development in the intensity of investigation. One indicator of this fact is the number of scientific papers that are published. A tool to count this number is google scholar. The number of papers without patents and citations was counted between the years 1997 and 2018. To get a better view also the terms Kaizen, Lean Management and Six Sigma are counted. The result is shown in Fig. 1.

For all four terms, nearly always an increase year by year is found. Until 2002, the dominating term was Kaizen. Afterward, a high increase of Six Sigma was detected. OPEX is mostly at the lowest level. However, this is no indicator of less relevance (see Fig. 2). To compare the different developments better, the quotient of "OPEX" to the other terms was calculated over the years. Is the quotient less than 
Fig. 1 the development of the numbers of scientific papers between 1997 and 2018 for the terms: OPEX, Kaizen, Lean Management and Six Sigma at google scholar

Fig. 2 The quotient of the different terms normalized to OPEX number of papers found google scholar

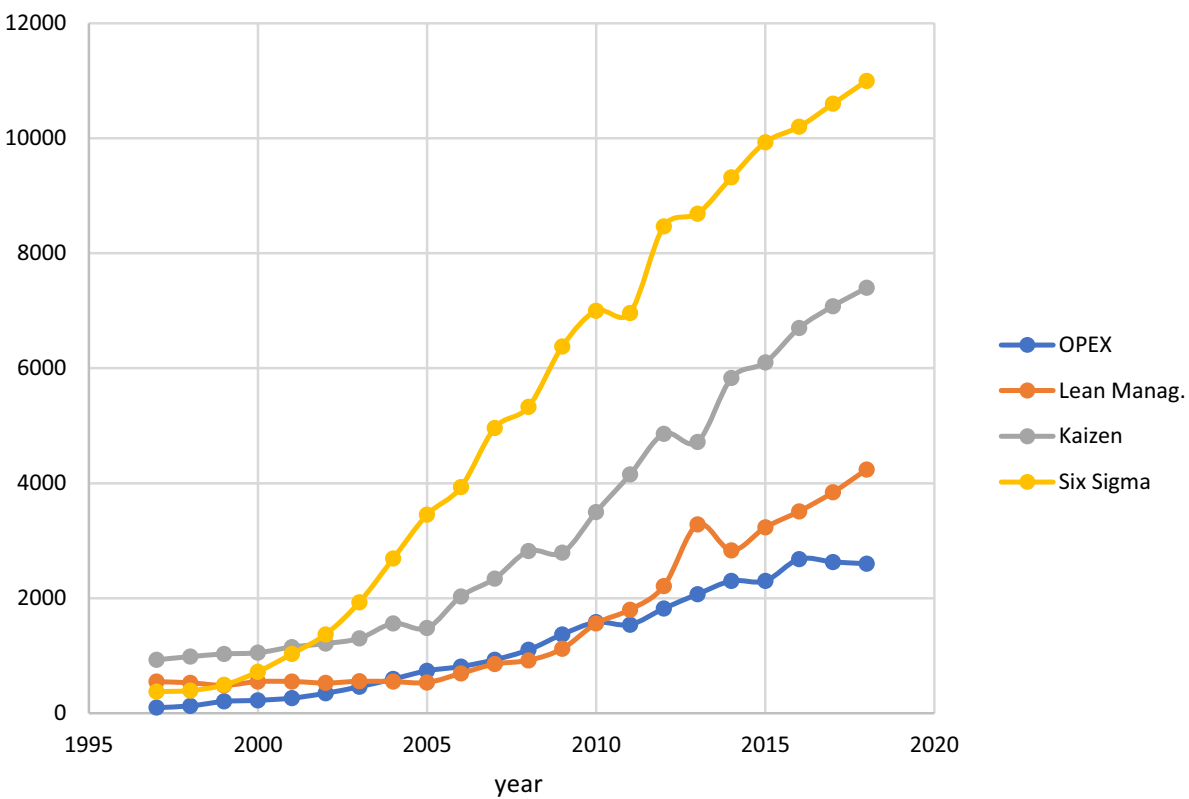

Ratio

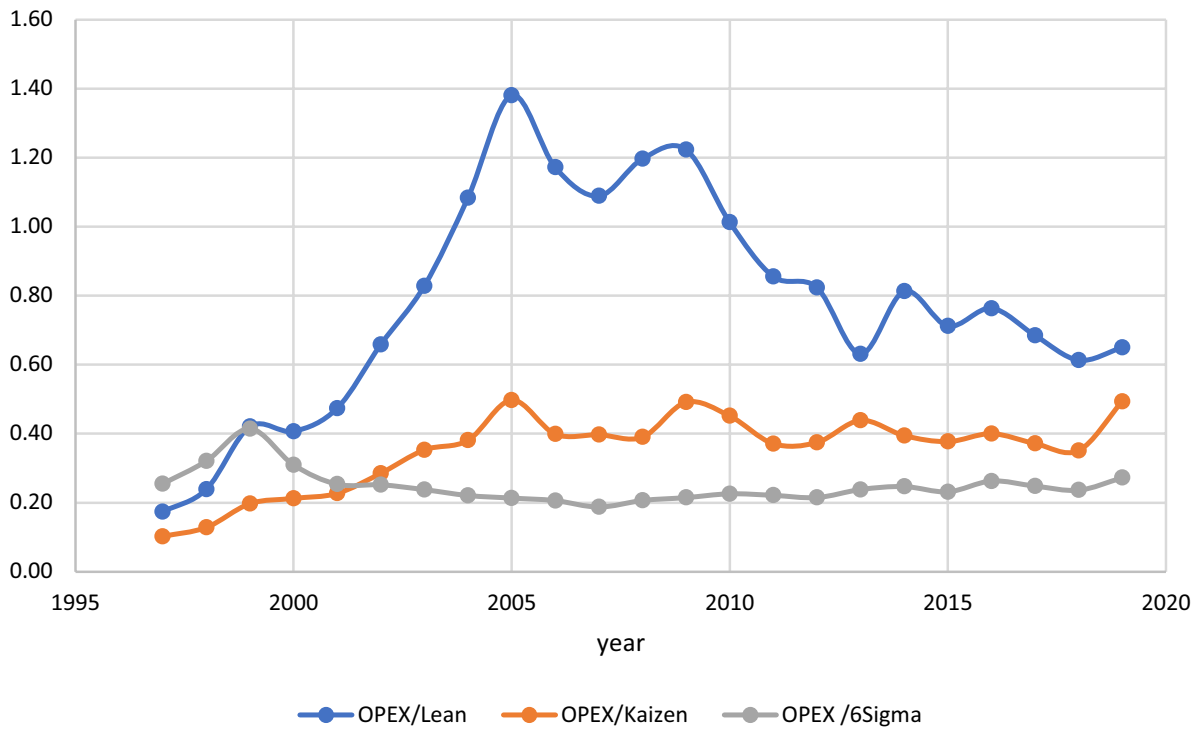

1, more papers were published in the related subject than OPEX. Higher than 1 means that more papers with the subject OPEX were published that articles with Six Sigma or Kaizen. What is more interesting is if the quotient is constant and gives a horizontal line.

- Six Sigma is very horizontal from 2000 to 2018 . A linear regression gives a slope $\mathrm{m}$ of $\mathrm{m}=+8 \times 10^{-5}$ with a reliability $R^{2}=0,999$, which is compatible with zero. For Kaizen, the trend between 2003 and 2018 is the same but with more deviations in different years.
- For Kaizen, from 2005 to 2018 the regression is also a horizontal line with a slope of $m=0.0028$ with a reliability of $93 \%$. The lower reliability is caused by bigger differences per year.

Summarized it can be said that within the errors both regressions are horizontal.

There is a different development with the term "OPEX". Between 2004 and 2010 more papers compared to the other subjects were published. The development after 2010 
is caused by the fact, that people see Kaizen, etc. as a part of OPEX.

To get a better overview and an indication for this development, now it was searched for papers, which contains both expressions in the publications. Figure 3 shows this development.

This is an upper limit for publications that have set Operational Excellence and the other subject in relation. The percentage for Lean Management and Kaizen is continuously increasing over the years. Since 2009 a saturation has been achieved for Six Sigma. The absolute error (one standard deviation) of each year is about $\pm 2 \%$, which is compatible with a straight line.

\section{Definitions}

After the first analyses described in chapter 2, it was found that many people, also in the scientific community, uses the phrase Operational Excellence but do not define it. Some take it in relation to Kaizen or Six Sigma. This was the motivation for making an investigation for a useable definition and perhaps to create a definition, which mirrors the actual situation.

31 different publications were proofed in the time range from 2012 to 2019. At first, the publications were sorted to definition is fulfilling the scientific demands. In a lot of publications, the references were missing or had no direct connection to the paragraph where the reference is used. Four of the publications use OPEX without defining it. At least 8 publications were used for further analysis.
Thomas Friedli and Daniel Bellm define OPEX as a continuous pursuit of improvement of production in all dimensions (Friedli et al. 2013) in their book. They see a way of continuous improvement which is related to production. Opex is seen as a process-orientated approach by Daniel Bloom OPEX (Bloom 2014). He sees the flow of values that needs to be kept running.

Bloom described OPEX by citing the view of Kevin Duggan (Duggan 2007). Duggan, therefore, sees OPEX as a process-orientated approach as well. He sees a flow to the customer, which has to be held up. This flow is not explained further (Bloom 2014).

In the same year, Govindsamy writes in his PhD-thesis, that there is no common definition existing. Everybody has its one model and therefore its own definition, which is inconsistent (Govindsamy 2014).

Jaegers and Matyas' key aspects are operations keeping up (long term process) the process of transforming inputs into outputs. Therefore, operations are necessary, which is the core of OPEX. All operations are subsumed under OPEX, which is embedded in business excellence (Jaeger and Matyas 2016).

A year later, concrete operations were mentioned by Muazo and Tasmin. They see Lean Management, Continuous Improving Process, and Six Sigma as part of process excellence including OPEX triggering optimal performance (Muazo and Tasmin 2017).

One of the newest definitions is from Cayho et. al. These authors see OPEX as a philosophy of continuous improvement in the organization. The purpose is to reach an optimum state of the process. This process should be lean-conform (Cahyo et al. 2019).

In the next chapter, the definitions are compared to get a better overview.
Fig. 3 Percentage of the publications containing both expressions

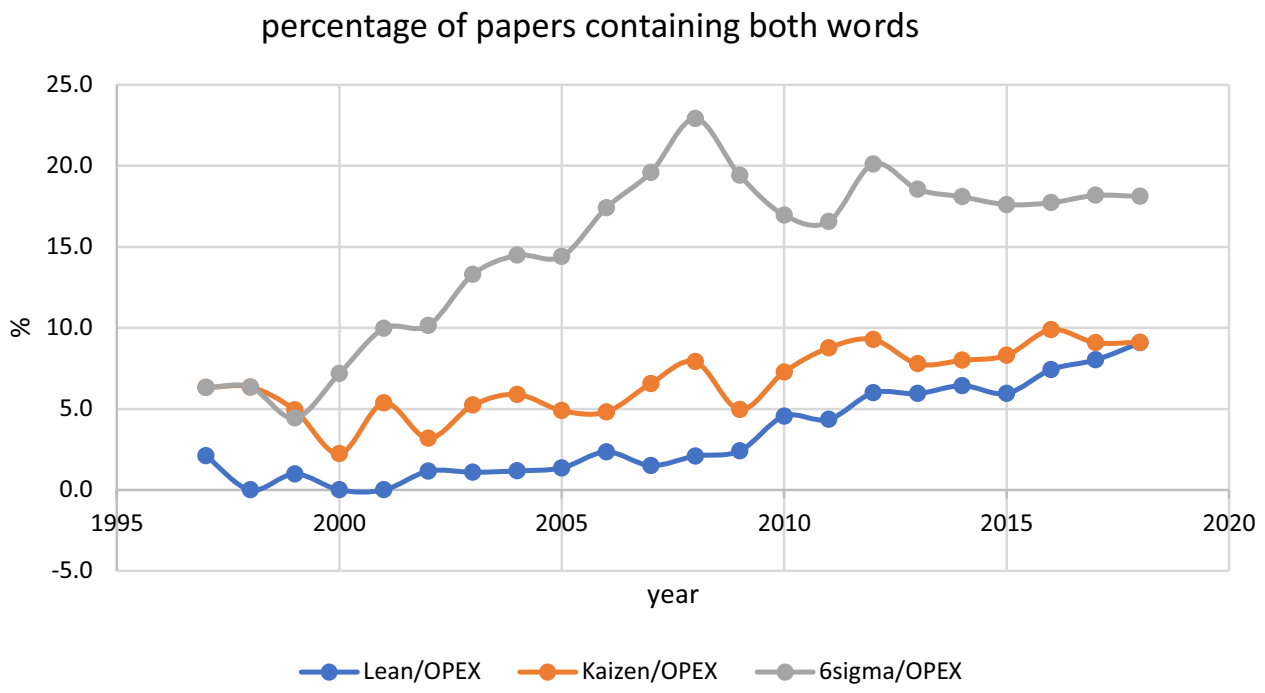




\section{Discussion of the definitions}

Looking at the development of this century a strong dynamic is seen as described by Fok-Yew and Ahmad (2014). Often, is it used without any concrete definition. The same aspects were stated by Samet Ilkay (Ilkay 2019) in his PhD-Thesis. With continuous progress, some elements will get common, but a strong dynamic can be detected (Liu 2017).

Looking to the beginning of the last two decades from 2000 to 2019 no concrete tools were given. Only a transforming process from input to output is stated. This means self-made tools were used (Cahyo et al. 2019). For example, it is described as an atmosphere to trigger the accomplishment of optimal performance (Muazu and Tasmin 2017). Looking at all the references in the first five years, OPEX can be summarized in the following model: (Fig. 4)

2017 (Muazu and Tasmin 2017) described tools Lean Management, Six Sigma, Continuous Improvement Process, and some company specified processes very concrete. Other authors like Cayho (Cahyo et al. 2019) also mentioned a standard tool like Continuous Improvement Process.

In an overall study by N. Landmann, H.-D. Schat and G. Schmidt-Meuter (Landmann et al. 2016, 2018) the authors show Kaizen and the employee suggestion system (ESS) as the main tools of the improvement process in a company in Germany, Austria, Switzerland, and Lichtenstein. In the study, $90 \%$ of the 261 investigated organizations have been using Kaizen as the head tool and $60 \%$ have been using ESS in different specificities (Landmann et al. 2018, p. 167). These numbers include the common use of both. However, the depth of implementation of both approaches is excluded in the study.

Supporting tools for a process like TQM or TPM play an important role along the process-chain that the main process is to transform an input value into an output value. A very clear description is given by the St. Gallen OPEX Model (Friedli et al. 2013). It is demanded by stable equipment, stable processes, and stable inventory. The performance of these demands is strongly linked with supporting tools to keep it stable.

Taking all the thoughts of the references which were published after 2005 in consideration, the old model can be modified by adding new tools, which have been defined clearly: (Fig. 5)

The model contains three sections. The self-modeled tools will be one part but have been reduced, because using standard tools is quicker and often tested. Standard tools mean the different methods out of the Lean Management toolbox. One tool, which can be summarized also under these tools is the employee suggestion system. ESS is well established in Germany (Landmann et al. 2018. The third big section is the supporting tools for the main (production) process.

Taking all aspects in consideration the definition of OPEX is:

Operational excellence overall deals with the efficiency and optimization of individual processes (Jaeger and Matyas 2016) and continuous improvement (Muazu and Tasmin 2017) over a mostly long period throughout an operation (Cahyo et al. 2019). Therefore operational excellence is rooted in different approaches like Lean Management, Six Sigma, (Muazu and Tasmin 2017) Business Process Management and continuous improvement or specific with the situation related processes (Muazu and Tasmin 2017).

Furthermore (Cahyo et al. 2019) operational excellence empowers employees by an atmosphere (Muazu and Tasmin 2017) within in company that triggers the accomplishment of optimal performance.

This will lead to lower operational risks, lower operations cost as well as increased revenues (Wilson Perumal 2019)
Fig. 4 Model of OPEX at the beginning of the last two decades from 2000 to 2019

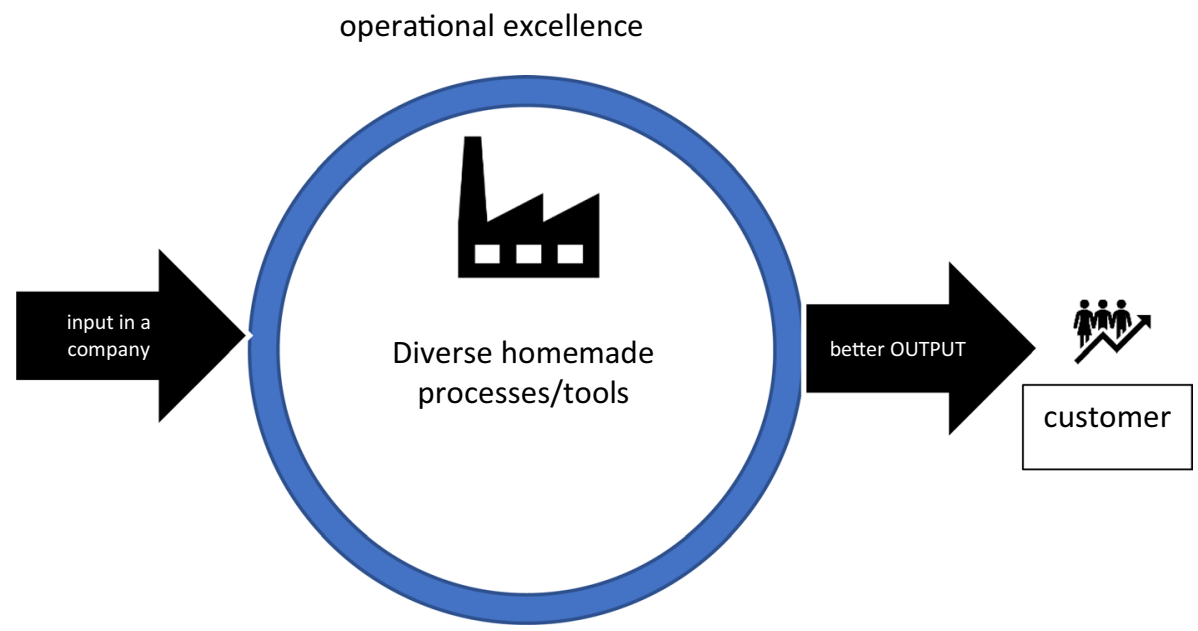


Fig. 5 New model of OPEX. ESS employee suggestion system

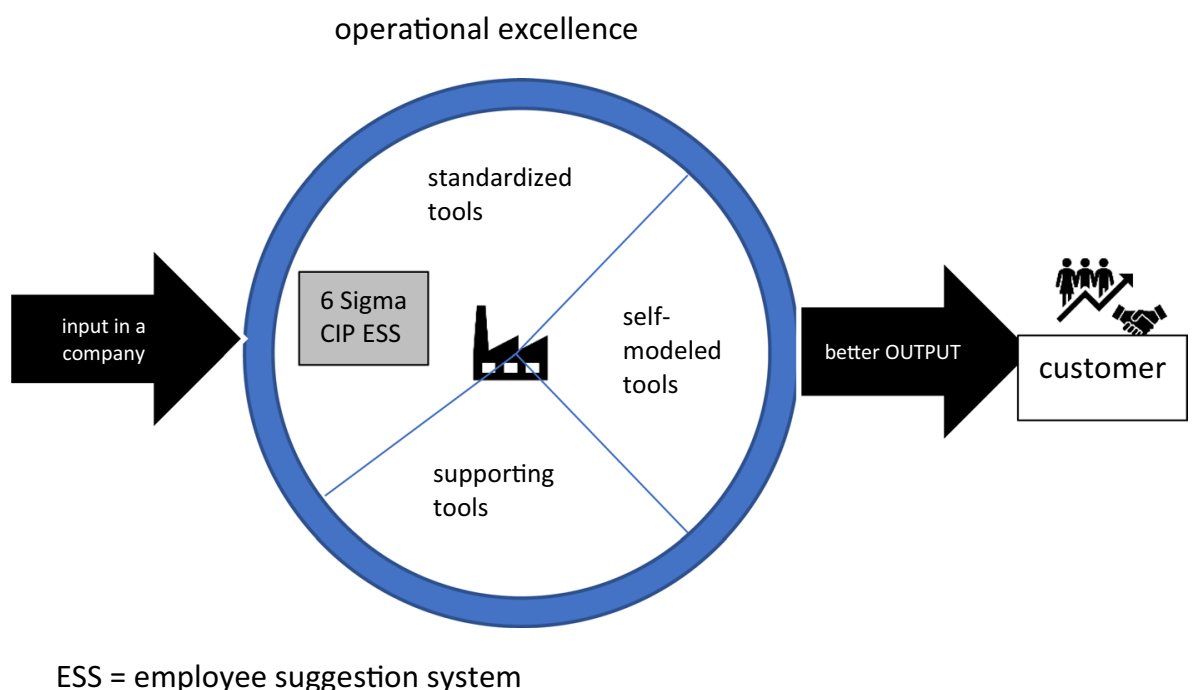

in addition to a more sustainable (Muazu and Tasmin 2017) customer satisfaction and loyalty.

In this definition the present discussions and understanding are summarized which can be used as a common base for further investigations or implementation of OPEX.

\section{OPEX and leadership}

It should be mentioned that successful OPEX can only be reached through leadership. The Boston scientific strategic operational excellence model (Found et al. 2018) shows that OPEX has started with a vision that is getting into reality. Kaizen is mentioned as one major tool for improving the results by defining modified goals to optimize OPEX. The success is not only determined by tools but also is leadership as a soft factor to fulfill economic goals.

Leadership can only be successful if the responsible persons have the necessary competences. A single person is not able to reach OPEX by himself for a whole institution or company. As a consequence, team leadership is one important aspect. Several papers mention (e. g. Zaccaro et al. 2001; Adair 2007; Mumford et al. 2007) that different types of leadership competences are necessary for making OPEX a successful implementation. However, OPEX can be used in many different situations. Comparing these competences to the key competences that are shown in the Kode ${ }^{\circledR}$ matrix of key competences (Heyse 2010) you can find a lot of overlapping between the described competences and OPEX.

\section{Conclusions}

The definition and understanding of Operational Excellence have been in a dynamic flow over the last 10 years. Many use the word OPEX without any definition. Books printed in a well-known publisher where OPEX is a topic do not define the term "OPEX". Sometimes OPEX is defined without any references from the literature. The common understanding is not very high. The suggested definition can be used to give a consolidated view of the topic. The definition should be scrutinized in short terms. The dynamic in the economic and scientific world is probably going to change quicker in the future. Leadership in conjunction with necessary (key) competences is one main factor to reach OPEX.

Funding No funding.

Open Access Dieser Artikel wird unter der Creative Commons Namensnennung 4.0 International Lizenz veröffentlicht, welche die Nutzung, Vervielfältigung, Bearbeitung, Verbreitung und Wiedergabe in jeglichem Medium und Format erlaubt, sofern Sie den/die ursprünglichen Autor(en) und die Quelle ordnungsgemäß nennen, einen Link zur Creative Commons Lizenz beifügen und angeben, ob Änderungen vorgenommen wurden. Die in diesem Artikel enthaltenen Bilder und sonstiges Drittmaterial unterliegen ebenfalls der genannten Creative Commons Lizenz, sofern sich aus der Abbildungslegende nichts anderes ergibt. Sofern das betreffende Material nicht unter der genannten Creative Commons Lizenz steht und die betreffende Handlung nicht nach gesetzlichen Vorschriften erlaubt ist, ist für die oben aufgeführten Weiterverwendungen des Materials die Einwilligung des jeweiligen Rechteinhabers einzuholen. Weitere Details zur Lizenz 
entnehmen Sie bitte der Lizenzinformation auf http://creativecommons .org/licenses/by/4.0/deed.de.

\section{References}

Adair JE (2007) Develop your leadership skills, vol 11. Kogan Page Publishers, London

Bloom D (2014) Achieving HR excellence through Six Sigma. CRC Press, Boca Raton

Cahyo WN, Prawahandaru H, Swasono BA, Raben RSI, Sutartono RT, Immawan T (2019) Data-based maintenance strategy analysis using operational excellence approach in engineering asset management. Int J Integrat Eng 11(5):222-228

Duggan K (2007) The journey towards operational excellence. Management Services Journal, Spring Edition, Heidelberg, p 26

Friedli T, Basu P, Bellm D, Werani J (2013) Leading pharmaceutical operational excellence. Leading pharmaceutical operational excellence outstanding practices and cases. Springer, Heidelberg, pp 411-418

Fok-Yew O, Ahmad H (2014) The effect of change management on operational excellence moderated by commitment to change evidence from Malaysia. Int J Innov Appl Studs 9(2):615

Found P, Lahy A, Williams S, Hu Q, Mason R (2018) Towards a theory of operational excellence. Total Qual Manag Bus Excell 29(9-10):1012-1024

Govindsamy N (2014) A critical review of operations excellence programs: a petrochemical company as case study (Doctoral dissertation, North-West University, Potchefstroom Campus).

Heyse V (2010) Kode ${ }^{\circledR}$ als Verfahrenssystem. In: Heyse V, Erpenbeck J, Ortmann S (eds) Grundstrukturen menschlicher Kompetenzen. Waxmann, Münster, p 81
Ilkay S (2019) Operative excellence in buyer-supplier relationships: the influence of operative antecedents on supplier satisfaction (Master's thesis, University of Twente).

Jaeger A, Matyas K (2016) Transformation of the EFQM approach from business towards operations excellence. Prod Eng Res Devel 10(3):277-291

Kagermann $\mathrm{H}$ et al (2013) Umsetzungsempfehlungen für das Zukunftsprojekt Industrie 4.0. Abschlussbericht des Arbeitskreises Industrie 4.0, acatech. Deutsche Akademie der Technikwissenschaften e.V, München

Landmann N, Schat H-D, Schmidt-Meuter G (2016) Erfolgsfaktoren im Ideenmanagement Studie 2016. HLP Informationsmanagement $\mathrm{GmbH}$, Eschborn

Landmann N, Schat H-D, Sieben T (2018) Erfolgsfaktoren im Ideenmanagement Studie 2018. HLP Informationsmanagement GmbH, Eschborn

Liu H (2017) The impact of owner practices and procedures on construction project safety performance. Doctoral dissertation, Theses and Dissertations - Civil Engineering, University of Kentucky.

Muazu MH, Tasmin R (2017) Operational excellence in manufacturing, service and the oil and gas: the sectorial definitional constructs and risk management implication. Traektoriâ Nauki Path Sci 3(9):3001

Mumford TV, Campion MA, Morgeson FP (2007) The leadership skills strataplex: leadership skill requirements across organizational levels. The Leadership Quarterly 18(2):154-166

Wilson Perumal (2019) https://www.wilsonperumal.com/blog/a-bette r-definition-of-operational-excellence. Accessed 3 Dec 2019

Zaccaro SJ, Andrea L, Rittman AL, Marks MA (2001) Team leadership. The Leadership Quarterly 12(4):451-483 